\title{
RELIGIOUS VALUES IN INDONESIA'S CHARACTER EDUCATION
}

\author{
Ahmad Nadhif \\ STAIN Ponorogo Jl. Pramuka No. 156 PO. BOX 116 Ponorogo 63471 \\ Email: nadheef@yahoo.com
}

\begin{abstract}
ABSTRAK
Penelitian ini bertujuan untuk menginvestigasi ideologi di balik peletakkan yang tercantum dalam Panduan Budaya dan Karakter Menteri Pendidikan yang diterbitkan pada tahun 2012. Penelitian ini dipaparkan sebagai bagian dari kurikulum pendidikan karakter dan memberi petunjuk pada guru tentang bagaimana melakukan implantasi untuk nilai-nilai moral yang baik dalam fikiran dan jiwa mereka. Isu pendidikan karakter menandai perubahan signifikan dalam kurikulum nasional pendidikan Indonesia yang menunjukkan potensi bagai pertarungan ideologi. Karenanya, hal ini merupakan isu penting untuk diteliti, khususnya dalam kajian Critical Discourse Analisis (CDA). Dengan menggunakan tiga model dimensional CDA Fairclough (1989), kurikulum Indonesia terkait dengan pendidikan berkarakter secara tekstual dianalisa. Analisa menunjukkan bahwa penggunaan nilai-nilai agama masih dipertanyakan; terkait dengan simbol dan jargon, agama sesungguhnya sangat dihargai; namun nampaknya hanyalah merupakan hal tak jelas untuk diam-diam menekan dan memarjinalkan core penting pengajaran.
\end{abstract}

Kata Kunci: Pendidikan karakter, Nilai agama, CDA

\section{ABSTRACT}

This study aims at investigating the ideology behind the positioning of religion included in the Guidance of Culture and Character of the Nation of the Ministry of Education published in 2010. It is presented as part of the curriculum of character education and prescribes for teachers on how to conduct the implantation of good moral values in their students' mind and heart. This issue of character education marks a significant shift in Indonesia's national curriculum of education showing a potential to be a conflicting battleground of ideologies. Hence, this is an essential issue to study, especially in the light of Critical Discourse Analysis $(C D A)$. By using three dimensional models of CDA's Fairclough (1989) the Indonesia's curriculum of character education is textually analyzed. The result of analysis shows that the use of religious values may still be questionable; in terms of symbols and jargons, religion is bighly valued; however, it seems to be only a disguise to silently suppress and marginalize its essential core of teachings.

Keywords: Character education, Religious values, $C D A$ 


\section{INTRODUCTION}

The function of education is to help people become what they are able to and supposed to be (Phenix: 1986). Many, however, consider that education in Indonesia has failed in doing this job, considering the fact that corruption and many other wrongdoings alarming a moral decadence are now widely spread in this country. Some argue that this phenomenon is caused by the negligence of character education during the so far teaching and learning process; and hence, it should be revitalized to solve the problem.

As a response to this suggestion, in 2010, the Indonesia's Ministry of Education released a guide book on what it calls "budaya dan karakter bangsa" (culture and character of the nation). It is intended to be a guidance of conducting character education at schools, not as a separated subject taught in a "moral class", but inserted in integration with all subject matters available (Ministry of Education: 2010, 13).

In this regard, religion is one of the main references of moral values, especially in pre-secularism era (Arthur: 200; Haydon: 2010), although some experts strictly differentiate between religion and morality (see Arthur: 2008; Elias: 2008). Indonesia definitely states that it is a country which believes in one God. However, concerning the global influence of Western culture and ideology and the fact that character education is likely the most conflicting battleground of ideology in educational field (Arthur: 2003), it is interesting to investigate how then religion is positioned in today's Indonesia's curriculum of character education.

To answer the question, Critical Discourse Analysis (CDA) is used as an analytical tool. It is promising for educational research (Rogers: 2004), including in the field of curriculum analysis. It enables the researchers to describe, interpret, and explain the relationship between language and vital educational issues (Rogers: 2004). Nevertheless, as cited by Granville (2010), Silverman (2007) notes that many qualitative researchers treat a document or a text as reference rather than an object to study.

This study aims at investigating how religion is positioned in the curriculum of character education in Indonesia. Revealing this philosophical concept of character education allows us to better evaluate this project of moral implantation. It is assumed that the success of a program also depends on its basic conception.

\section{ANALYSIS}

\section{Theoretical Foundation}

Two issues are addressed in this section: two conflicting perspectives (religious and secular ones) on the role of religion in education (excluding the Marxist's standpoint due to its irrelevance with Indonesia's belief in God) and some basic principles of CDA. 


\section{Religion and Moral Values in Education}

Education is to shape human being into what they should be, meanwhile all humankinds (will) experience, nullifies "the meaning of life" (Phenix: 1986, 32). With this idea in mind, the debate on what form human being should be shaped by education has to include the discussion about the reality or more exactly the belief about reality after death. And this topic is mainly addressed in religion.

In the late 19th century, especially in Christian community, the teaching of religion and the teaching of morality is regarded the same thing in educational field. Arthur (2003: 15) suggests "the distinct moralistic strain in Protestantism strengthened the general assumption that moral instruction was synonymous with religious instruction and if this was not always the case, then religion could certainly be relied upon to aid moral instruction"

Also, according to Haydon (2010: 198), before 1990s, England saw that religion is "the vehicle of moral education". Moreover, Carr and Mitchell (2007) assert that the Judeo-Christian worldview will never regard human being in isolation from their relationship with God.

The theistic approach in Islam also shares this perspective of Godrelatedness. An-Nabahani, a Palestinian Islamic Jurist, asserts that an action to be accepted as being Islamic should be done in awareness of relationship with God. He argues, "An action is a matter, and the comprehension of the relationship with Allah when performing this action is spirit (rub). Thus directing one's actions according to the commands and prohibitions of Allah -- based on the comprehension of this relationship -- is mixing matter with rub" (AnNabahani, 2002: 88).

However, secularism has different idea. This system suppresses religion and spirituality in education curriculum (Carr \& Mitchell, 2007). It is also criticized for producing "value-free" and "value-neutral" education (Brown: 2007, 212). Nevertheless, secularism is actually not about eradicating religion from life. Its concern is only to separate religion from public life. In the educational context, it is manifested extremely by exclusion of religion in the process of teaching and learning, or moderately by putting religion in a separated position even from what the so called moral values. The best example of this can be seen in how Philip H. Phenix develops his argument about six realms of meanings.

Phenix(1986: 21) argues that in their life, human being does constantly search what he calls "meanings" and suggests that there are six realms of them, namely symbolic, empirics, esthetics, ethics, and synoptic. Religion is included in the last meaning, synoptic, together with history and philosophy. Meanwhile, moral goes to the fifth realm: ethics. Here, very different from religious perspective above, religion is assumed to be a separate thing from morality and character. In other words, whatever religion one adheres to (and even a person with no religion at all), he or she surely may holds high morality." 


\section{CDA as a tool of analysis}

Wodak (2001a) suggests that CDA deals with "analyzing opaque as well as transparent structural relationships of dominance, discrimination, power and control as manifested in language". Meanwhile, van Dijk (2001) objects the assumption that CDA is a theory or a method. Instead, he asserts, it is a perspective which is critical in doing a scholarship, focusing on social problems and often taking the side of the dominated groups. I myself would define CDA as an approach to the study of discourse that views language as social activity and aims at revealing how social power operates within a text.

a. Basic notions of $\mathrm{CDA}$

There are two central terms in the CDA: discourse and ideology (Pennycook: 2001).By linguists such as Fairclough, Wodak, and van Dijk, discourse is generally understood as language in use, while ideology is a specific framework of knowledge related to social power and probably evident in language (Pennycook: 2000; see also Fairclough (2003) and Weiss and Wodak (2003).

In CDA, text is understood in a broad sense. As a language in use, it is not only in the written form, but also in the spoken and visual ones (see Fairclough: 2003), and it is always connected to social life. It may even lead to social changes (Fairclough: 2003).

Moreover, issue of power relation is also central to the discussion of CDA. It is worth-noted here that CDA stems from critical theory, the normative base of which, as in compassion, in our sense for the suffering of others (Pennycook: 2001, 6). However, Van Dijk (1993) reminds us that what the so called power relation does not necessarily mean to domination going down from top to bottom, but it may also be in the form of resistance, compliance and acceptance from bottom up to the top. For that reason, in my opinion, the doer of power abuse should not be confined only to the dominating group, but also to those struggling for power. In this regard, always taking the side of the "oppressed" group is not fair, and maybe nor "critical". Wodak (2001b) suggests that CDA is not about right or wrong, but about making choices transparent and justifying why they are more valid than the others.

b. Methods of CDA

Actually there is no single method or how-to procedure of doing CDA (Meyer: 2001; van Dijk: 2001) nor accepted canon of data collection (Meyer: 2001). Indeed, CDA can be done in or combined with any approach in social sciences (van Dijk: 2001). The variety of analytical approaches range from grand theories, micro-sociological theories, socio-psychological theories, discourse theories, to linguistic theories (Meyer: 2001). According to van Dijk (2001), one of CDA's volitional characteristics is its diversity. However, Meyer (2001) suggests that all approaches share the principle that "operationalization and analysis are problem oriented and implies linguistic expertise". 


\section{c. Criticism on $\mathrm{CDA}$}

According to Meyer (2001), one of the prominent figures criticizing CDA is Henry Widdowson. He asserts that CDA is not only vogue but also "vague" and believes that CDA is a biased interpretation. In response to this criticism Fairclough (1995) invites to see the open-endedness of result required by CDA principles. Meanwhile, van Dijk (2001) suggests that CDA is, yes, "biased" but it is "proud of it". After all, is it possible to perform any analysis that is completely free from a priori value judgment? I think it is not.

The data analyzed is the guidance book entitled Pedoman Budaya dan Karakter Bangsa released in 2010 by the Curriculum Centre of Indonesian Education Ministry.

Due to the nature of the data and the analytical framework, the main instrument is the researcher himself. Hence, subjectivity, however small the amount is, is unavoidable. Indeed, following the principle of critical theory, I would argue that there by a hair's breadth is research being free from value and interest. The level of subjectivity can be decreased and responsible upon by tagging faithfully on certain approaches or models.

Although van Dijk (2001) claims that adopting a certain CDA approach may indicate not being critical, a novel analyst is still necessary to follow a certain qualified approach in his or her research. This study adopts Fairclough's three dimensional models (Fairclough, 1989). These three dimensions are:

1. The object of analysis (including verbal, visual or verbal and visual texts)

2. The processes by means of which the object is produced and received writing/speaking/designing and reading/listening/viewing) by human subjects

3. The socio-historical conditions which govern these processes.

Each dimension requires different kind of analysis; they are respectively text analysis or description, processing analysis or interpretation, and social analysis or explanation. According to Janks (1997), this approach allows us "to focus on the signifiers that make up the text, the specific linguistic selections, their juxtapositioning, their sequencing, their layout and so on".

\section{Findings and Discussion}

Following Fairclough's three-dimensional model (1989), in this section I wrap up the data found and the discussion about it in three stages, each of which has different focus but interrelated to each other.

\section{Dimension 1: Description (text analysis)}

There are two types of text to elaborate: visual and written ones. The visual text comprises of 23 pictures (including the logo of "Tut Wuri Handayani" and "garuda pancasila"), while the written one is made of 22,663 words in 124 A4-size pages. Certainly, only those phrases and picture I think directly relevant to the research problem is analyzed. 
Seven out of 22 pictures $(32 \%)$ in the document contain symbols of religion (i.e. veils and peci haji-s). It indicates that religion, especially Islam, is given relatively high credit within this guidance book. To transfer the impression made by the pictures to the readers, two out of seven "religious pictures" are shown below.

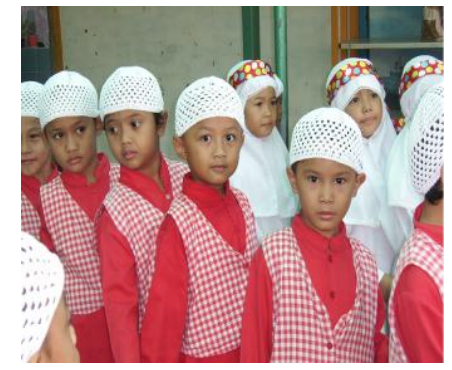

Picture 1 (p. 9)

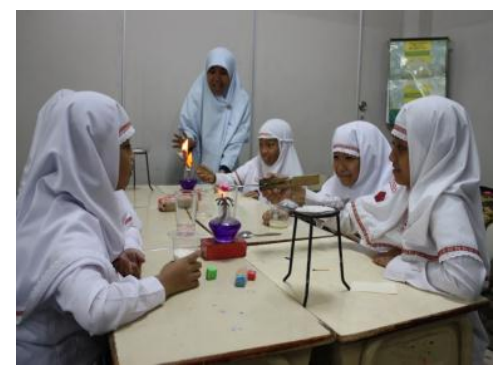

Picture 5 (p. 14).

Although the writer team of this Guidance book explains that these pictures shows the values of discipline and active learning, the veils, the peci-s, and the koko-s put on by the students and the teacher convey the author's Islamic ideology. In this regard, one may critically question this dominating Islamic perspective compared to other religions, but in this very moment I only highlight that religious symbols are to some extent glorified.

Furthermore, the writer team shows their concerns of the important role of religious values in character education. For example, on page 7 , the team states as below:

Oleh kearena itu pendidikan budaya dan karakter bangsa pada dasarnya adalah pengembangan nilai-nilai yang berasal dari pandangan bidup atau ideology bangsa Indonesia, agama, budaya, dan nilai-nilai yang terumuskan dalam tujuan pendidikan nasional. (Therefore, education of nation's culture and character essentially is development of certain values derived from Indonesian worldview or ideology, religion, and other values formulated in the national educational goals).

Importantly, religious values are always ranked at the first place before others in many places of the Guidance book. In the discussion of Nilai-Nilai dalam Pendidikan Budaya dan Karakter Bangsa (Values in The Education of Nations' Culture and Character) (2010, 8), the values of religion are mentioned in the first portion, followed by values of Pancasila (the first verse of which is "ketuhanan yang Maha Esa", such kind of belief in one God), Budaya, and Tujuan Pendidikan Nasional (of which Iman-being faithful- and takwa -being piousare the first items). From these four sources of values, the writer team, further, delineates 18 different values, the first of which is again "religious".

The following is the complete list of the values: 
1. Religius(religious)

2. Jujur (honest)

3. Toleransi (tolerance)

4. Disiplin (discipline)

5. Kerja keras (hard work)

6. Kreatif (creative)

7. Mandiri (self-reliance)

8. Demokratis (democratic)

9. Rasa ingin tabu (curiosity)

10. Semangat kebangsaan (nationalism)

11. Cinta tanab air (loving the nation)

12. Menghargai prestasi (appreciating achievement)

13. Bersahabat/komunikatif (friendly/communicative)

14. Cinta damai (peace lover)

15. Gemar membaca (reading lover)

16. Peduli lingkungan (care of environment)

17. Peduli social (care of society)

18. Tanggung jawab (responsibility)

Special reference to the first value, namely religion; it is described, "Sikap dan perilaku yang patuh dalam melaksanakan ajaran agama yang dianutnya, toleran terhadap pelaksanaan ibadah agama lain, dan hidup rukun dengan pemeluk agama lain." (having obedient attitude and behavior in conducting religious teachings that students adhere, being tolerant to other performance of religious teachings, and living in peace with other religions' adherents) (The Ministry of Education: 2010, 9).

The implantation of religious values is considered successful in accordance with the following indicators (p. 26):

1. School indicators:

- Merayakan hari-hari besar keagamaan (celebrating religious feasts)

- Memiliki fasilitas yang dapat digunakan untuk beribadab (providing facilities used for performing religious teachings)

- Memberikan kesempatan kepada semua peserta didik untuk melaksanakan ibadah (providing opportunities to students of performing religious teachings).

2. Class indicators:

- Berdoa sebelum dan sesudah pelajaran (reciting prays before and after study)

- Memberikan kesempatan kepada semua peserta didik untuk melaksanakan ibadah (providing opportunities to all students to perform religious teachings).

3. And the following list is the indicators of being religious among students (beginning from year 1 of elementary schools to year 12 of senior high schools): 
Table 1. Indicators of Religious Value among Students of Elementary School

\begin{tabular}{|c|c|c|}
\hline \multirow{2}{*}{ RELIGIOUS VALUE } & \multicolumn{2}{|c|}{ INDICATOR } \\
\hline & $1-3$ & $4-6$ \\
\hline \multirow[t]{3}{*}{$\begin{array}{l}\text { Obedient attitudes and } \\
\text { behaviors in } \\
\text { implementing } \\
\text { the teachings of the } \\
\text { religion adhere to } \\
\text { students, tolerant to } \\
\text { worship performed by } \\
\text { other } \\
\text { religions'adherents, and } \\
\text { living in } \\
\text { harmony with other } \\
\text { religious believers. }\end{array}$} & $\begin{array}{l}\text { Mengenal dan mensyukuri tubub dan } \\
\text { bagiannya sebagai ciptaan Tuban } \\
\text { melalui cara merawatnya dengan baik } \\
\text { Recognizing and praising human } \\
\text { body and its parts as the creation } \\
\text { of God showing by taking good } \\
\text { care of it }\end{array}$ & $\begin{array}{l}\text { Admiring } \\
\text { system and procedure } \\
\text { of human organs working } \\
\text { in perfect synchronizing } \\
\text { functions }\end{array}$ \\
\hline & $\begin{array}{l}\text { Mengagumi kebesaran Tuhan karena } \\
\text { kelabirannya di dunia dan hormat } \\
\text { kepada orang tuanya } \\
\text { Admiring the glory of God } \\
\text { because of students' coming into } \\
\text { the world and showing respect to } \\
\text { their parents }\end{array}$ & $\begin{array}{l}\text { Bersyukur kepada Tuban } \\
\text { karena memiliki keluarga yang } \\
\text { menyayanginya. } \\
\text { Praising God because of } \\
\text { students having family that } \\
\text { love them }\end{array}$ \\
\hline & $\begin{array}{l}\text { Mengagumi kekuasaan Tuban yang } \\
\text { telab menciptakan berbagai jenis } \\
\text { bahasa dan suku bangsa } \\
\text { Admiring the power of God } \\
\text { having created various languages } \\
\text { and ethnics }\end{array}$ & $\begin{array}{l}\text { Merasakan kekuasaanTuban } \\
\text { yang telah menciptakan } \\
\text { berbagai keteraturan dalam } \\
\text { berbahasa } \\
\text { Understanding the power } \\
\text { of God having created } \\
\text { various regularities in } \\
\text { languages }\end{array}$ \\
\hline & $\begin{array}{l}\text { Senang mengikuti aturan kelas dan } \\
\text { sekolab untuk kepentingan bidup } \\
\text { bersama }\end{array}$ & $\begin{array}{l}\text { Merasakan manfaat aturan } \\
\text { kelas dan sekolah sebagai } \\
\text { keperluan untuk bidup }\end{array}$ \\
\hline
\end{tabular}




\begin{tabular}{|c|c|c|}
\hline \multirow{2}{*}{ RELIGIOUS VALUE } & \multicolumn{2}{|c|}{ INDICATOR } \\
\hline & $1-3$ & $4-6$ \\
\hline & $\begin{array}{l}\text { Being happy to follow rules in } \\
\text { class and school for the sake of } \\
\text { living together }\end{array}$ & $\begin{array}{l}\text { bersama } \\
\text { Understanding advantages } \\
\text { of class and school rules as } \\
\text { necessity for living } \\
\text { together }\end{array}$ \\
\hline & $\begin{array}{l}\text { Senang bergaul dengan teman sekelas } \\
\text { dan satu sekolah dengan berbagai } \\
\text { perbedaan yang telab diciptakan-Nya } \\
\text { Being happy to hang out with } \\
\text { classmates and schoolmates } \\
\text { having various backgrounds } \\
\text { created differently by Him }\end{array}$ & $\begin{array}{l}\text { Membantu teman yang } \\
\text { memerlukan bantuan sebagai } \\
\text { suatu ibadah atau kebajilkan } \\
\text { Helping friends needing } \\
\text { assistance as a worship or } \\
\text { virtue }\end{array}$ \\
\hline
\end{tabular}

Table 1. Indicators of Religious Value among Students of Senior High School

\begin{tabular}{|c|c|c|}
\hline \multirow{2}{*}{ RELIGIOUS VALUE } & \multicolumn{2}{|c|}{ INDICATOR } \\
\hline & $7-9$ & $10-12$ \\
\hline $\begin{array}{l}\text { Sikap dan perilaku yang } \\
\text { patuh dalam melaksanakan } \\
\text { ajaran agama yang } \\
\text { dianutnya, toleran terhadap } \\
\text { pelaksanaan ibadah agama } \\
\text { lain, dan bidup rukun } \\
\text { dengan pemeluk agama lain }\end{array}$ & $\begin{array}{l}\text { Mengagumi kebesaran Tuhan melalui } \\
\text { kemampuan manusia dalam } \\
\text { melakukan sinkronisasi antara aspek } \\
\text { fisik dengan aspek. kejiwaan }\end{array}$ & $\begin{array}{l}\text { Mensyukuri keunggulan } \\
\text { manusia sebagai makbluk } \\
\text { pencipta dan penguasa } \\
\text { dibandingkan makbluk lain }\end{array}$ \\
\hline \multirow[t]{2}{*}{$\begin{array}{l}\text { Obedient attitudes and } \\
\text { behaviors in } \\
\text { implementing } \\
\text { the teachings of the } \\
\text { religions of students } \\
\text { believing in, tolerant to } \\
\text { worship of other } \\
\text { religious adherents, and } \\
\text { living in } \\
\text { harmony with other } \\
\text { religious believers. }\end{array}$} & $\begin{array}{l}\text { Admiring the greatness of } \\
\text { God through human capabilities } \\
\text { in synchronizing physical and } \\
\text { psychological aspects }\end{array}$ & $\begin{array}{l}\text { Praising human } \\
\text { excellence of being the } \\
\text { creator and ruler in } \\
\text { comparison toto other } \\
\text { creatures }\end{array}$ \\
\hline & $\begin{array}{l}\text { Mengagumi kebesaran Tuhan karena } \\
\text { kemampuan dirinya untuk bidup } \\
\text { sebagai anggota masyarakat. } \\
\text { Admiring the greatness of God } \\
\text { due to their abilities of living as }\end{array}$ & $\begin{array}{l}\text { Bersyukur kepada Tuban } \\
\text { karena menjadi warga bangsa } \\
\text { Indonesia } \\
\text { Praising to God due to }\end{array}$ \\
\hline
\end{tabular}




\begin{tabular}{|c|c|c|}
\hline \multirow{2}{*}{ RELIGIOUS VALUE } & \multicolumn{2}{|c|}{ INDICATOR } \\
\hline & $7-9$ & $10-12$ \\
\hline & members of society & being Indonesian citizens \\
\hline & $\begin{array}{l}\text { Mengagumi kekuasaan Tuhan yang } \\
\text { telah menciptakan berbagai alam } \\
\text { semesta } \\
\text { Praising the greatness of God for } \\
\text { His creation of all the universe }\end{array}$ & $\begin{array}{l}\text { Merasakan kekuasaanTuban } \\
\text { yang telah menciptakan } \\
\text { berbagai keteraturan di alam } \\
\text { semesta } \\
\text { Understanding the power } \\
\text { of God for His creation of } \\
\text { various orders of the } \\
\text { universe }\end{array}$ \\
\hline & $\begin{array}{l}\text { Mengagumi kebesaran Tuhan karena } \\
\text { adanya agama yang menjadi sumber } \\
\text { keteraturan bidup masyarakat } \\
\text { Praising the greatness of God } \\
\text { because of existing religions } \\
\text { emerging sources of social order }\end{array}$ & $\begin{array}{l}\text { Merasakan kebesaran Tuban } \\
\text { dengan keberagaman agama } \\
\text { yang ada di dunia } \\
\text { Understanding the } \\
\text { greatness of God for } \\
\text { varieties of existing } \\
\text { religions in the world }\end{array}$ \\
\hline & $\begin{array}{l}\text { Mengagumi kebesaranTuban melalui } \\
\text { berbagai pokok bahasan dalam } \\
\text { berbagai mata pelajaran } \\
\text { Praising the greatness of God } \\
\text { through various main topics of } \\
\text { various subject materials }\end{array}$ & $\begin{array}{l}\text { Mengagumi kebesaran Tuhan } \\
\text { melalui berbagai pokok } \\
\text { bahasan dalam berbagai mata } \\
\text { pelajaran } \\
\text { Praising the greatness of } \\
\text { God through various main } \\
\text { topics of various subject } \\
\text { materials }\end{array}$ \\
\hline
\end{tabular}

\section{Dimension 2: Interpretation (processing analysis)}

Firstly, I need to point out how power is exercised here. This is important to see how the text's attitude toward the role of religion in education is justified.

The text is written in a formal Indonesian language. It is also not shown who the writer(s) is, except that this book is released by the Curriculum Centre of The Ministry of National Education, entitled with the word "pedoman" (guidance). Moreover, in delivering the messages, the writer/team often does it in a strong way. Throughout the text, the tone of the language is that of language of instruction and commando. These features help to increase the authority of the text, and within this medium, power relation is constructed. The following are some examples. 
Oleb karena itu, guru dan sekolah perlu mengintegrasikan nilai-nilai yang dikembangkan dalam pendidikan budaya dan karakter bangsa ke dalam Kurikulum Tingkat Satuan Pendidikan (KTSP), Silabus dan Rencana Program Pembelajaran (RPP) yang sudab ada. (Therefore, teachers and schools are necessary to integrate values developed in education of nation's culture and character into the Curriculum of Education Unit Level, Syllabus and Planning of Teaching and Learning Program those are available)(2010: 11).

In this excerpt, the use of "perlu" as a modality serves to strengthen the message that it is the teachers' and schools' obligation to integrate the prescribed moral values into their teaching process. The writer/writing team positions himself as the power holder and treats the teachers and schools as the less powerful parties. This inequality is maintained right through the text. The following example shows clearer hegemony of the writer.

Berikut prinsip-prinsip yang digunakan dalam pengembangan pendidikan budaya dan karakter bangsa (the following principles are used to develop education of nation's culture and character) (2010: 11).

The sentence above contains no modality, suggesting an absolute message disallowing compromise. Under such hegemonic relationship, it may be rather difficult for a teacher to be critical in reading this guidance. The shocking finding of this analysis is that regardless the religious symbols glorified in the pictures and the "listing strategy" to make the religious values seem to be the most important among others, the indicators of being religious developed by the author clarify how marginalized is actually the religious values within the document.

To be "religious", it is enough for the school and class to celebrate religious ceremony events, facilitating students with worship facilities, praying before and after class hours, and letting people perform their different religious obligations. In other words, it is not necessary for the school and class to create religious atmosphere in terms of making serious attempts to make the students think and act based upon their religious teachings. The institutions only facilitate the performance of religious obligations if the students want to do so. If not, nothing will happen.

The same thing happens to the student's religious indicators. These are the main verbs: mengenal (acknowledge), mensyukuri (thank), mengagumi (get amazed), merasakan (feel), senang (be happy), membantu (help). All these verbs are mental verbs, happening only in mind, except for the last verb, membantu, which is materialized in concrete action. Amazingly, this single materialized verb is only for the elementary students! Thus, it gives more impression that religion is confined inside individual's head and has very little thing to do with public matters. 
Finally, when the author put a religious value in the first rank among the other 17 values, it does not only mean that religion is dignified as if it were the most important and fundamental, but neither means that the other 17 values are regarded as values outside the domain of religion. Hence, honesty, creativity, responsibility, and many other moral values are assumed to have nothing to do with religion.

\section{Dimension 3: Explanation (social analysis)}

In the lens of Critical Discourse Analysis (CDA), discourse does constitute society and culture, and at the same time being constituted by them. The insertion of pictures showing rich symbols of religion is influenced by the reality in the society. Different from two or three decades ago, in which jilbab is almost prohibited in public schools, nowadays many Muslim women use it to define their identity, even in public life such as schools or workplaces.

This increasing religious awareness among people seems to play important role in shaping the discourse to be at least symbolically represents the society.

However, it has been revealed that in the curriculum document of Pedoman Budaya dan Karakter Bangsa the substance of religious values is not treated in the same way as its symbols. While the symbols are glorified and positioned in the highest rank, the essence of it is clearly marginalized in a very limited individual sphere. A religion is seen to be far remotely separated from moral values. This obviously contradicts the theistic principle of at least Christianity and Islam, which both assert that any action, including that of morality, should be conducted in the basis of relationship-awareness with God Almighty (see anNabahani:2002, 88; Carr and Mitchell: 2007, 296; Haydon: 2010, 198; and Arthur: 2003, 15).

The still world-dominating ideology of Western secularism seems to influence and underlie the positioning of religion within the document.

\section{CONCLUSION}

The aim of this research is investigating how religion is positioned in the curriculum document of culture and character education in Indonesia. Through the lens of CDA, this study unveils the hidden ideology underlying the text analyzed, which is secularism. First of all, the research makes clear how in terms of symbols and "surface structure", religion is highly valued; head covering school students of both boys with peci and baju koko for their shirt, and girls with hijab and long blouses and dresses or baju muslimah. However, these symbols seem to be only a disguise to silently suppress and marginalize its essential core of teachings, which are shaping human being's way of thinking and acting into what they should be. The second dimension is clearly proved that the document of the Guidance book write that facilities to perform any kind of worships are provided for individual actions of students without commanding that teachers and all school staffs should provide practical guidance altogether. Verbs used in 
the document show that they are mental actions which could not be interpreted concretely by elementary school students. The last dimension proves that rich symbols of religious values are influenced by the reality in the society; which show gradual increasing implementation of religious values among Muslims in the recent time.

To sum up, in my opinion the document of the Guidance of the Culture and Character of the Nation gives the impression of being suffering from confusion in confidently positioning religion in the moral teaching project. With this internal confusion in the underlying philosophical concept of character building, it is unlikely that this project will gain success in the near time.

\section{BIBLIOGRAPHY}

An-Nabahani, Taqiuddin. 2002. System of Islam (translation). London: al-Khilafah Publication

Arthur, James. 2003. Education with Character: the Moral Economy of Schooling. London: Routledge Falmer

Arthur, James. 2008. Traditional Approaches to Character Education in Britain and America, in Nucci, L.P. \& Narvaez, D. (eds) Handbook of Moral and Character Education p, 80-98

Brown, David H. 2007. A Vision Splendid? The National Initiative in Values Education for Australian Schooling in Aspin, D. N. and Chapman, J.D. (eds) Values Education and Lifelong Learning: Principles, Policies, Programmes, p. 211-237

Carr, N. \& Mitchell, J. 2007. The Neglected Role of Religion and Worldview in Schooling for Wisdom, Character, and Virtue, in Aspin, D. N. and Chapman, J.D. (eds) Values Education and Lifelong Learning: Principles, Policies, Programmes, p. 295-314

vanDijk. "Principles of Critical Discourse Analysis", Discourse \& Society 4, 2, 1993 vanDijk, TA. 2001. Multidisciplinary CDA: a Plea for Diversity, in Wodak and Meyer (eds), Methods of CDA, p 95-120.

Elias, M.J., Parker, S.J., Kash, V.M., Weisberg, R.P., \& O’Brien, M. 2008. Social and Emotional Learning, Moral Education, and Character Education: A Comparative Analysis and a View Toward Convergence, in Nucci, L.P. \& Narvaez, D. (eds) Handbook of Moral and Character Education. p, 248-266

Fairclough, N. 1989.Language and Power. New York: Longman.

Fairclough, N. 2003. Analysing Discourse: Textual Analysis for Social Research. London: Routledge.

Granville, Gary. 2010. Curriculum Development as a Subversive Activity? Discourse and Ideology in the Evolution of Curriculum Policy in Ireland 1980-2005. EdD Thesis, NUI Maynooth.

Haydon, Graham. 2010. Values and Wellbeing in the Curriculum: Personal and Public Dimensions, in Lovat, T., Toomey, R., \& Clement, N. (eds) 
International Research Handbook on Values Education and Student Wellbeing p, $195-210$

Janks, Hillary. "Critical Discourse Analysis as a Research Tool".Discourse: Studies in the Cultural Politics of Education, 18, 3, 1997

Meyer, M. 2001. Between Theory, Method, and Politics: Positioning of the Approaches to CDA, in Wodak and Meyer (eds), Methods of Critical Discourse Analysis, p 14-31.

Pennycook, Alastair. 2001. Critical Applied Linguistics: a Critical Introduction. New Jersey: Lawrence Erlbaum Associates, Inc.

Phenix, Philip H. 1986.Realm of Meaning: a Pbilosophy of the Curriculum for General Education. California: Princarft, Inc.

Rogers, Rebecca (ed). 2004. an Introduction to Critical Discourse Analysis in Education. New Jersey: Lawrence Erlbaum Associates, Inc.

Weiss, G. \&Wodak, R. 2003. Introduction: Theory, Interdisciplinary and CDA, in Weiss and Wodak (eds) CDA: Theory and Interdisciplinary. New York: Palgrave Macmillan.

Wodak, Ruth. 2001a. What CDA is about - a Summary of its History, Important Concepts, and it's Development, in Wodak and Meyer (eds), Methods of Critical Discourse Analysis, p 1-13.

Wodak, Ruth. 2001b. The Discursive-historical Approach, Wodak and Meyer (eds), Methods of Critical Discourse Analysis, p 63-94.

*For further discussion about secular insight in character education, one may refer to Arthur's article Traditional Approaches to Character Education in Britain and America (Arthur, 2008). 